TURIZAM

Volume 21, Issue 2

90-101 (2017)

ORIGINAL

SCIENTIFIC PAPER

\title{
Foreign Tourists' Risk Perceptions About Turkey: An Application In Antalya Region
}

\author{
Yenal YağmurA, Oğuz Doğan ${ }^{B}$ \\ Received: May 2017 | Accepted: Jun 2017 \\ DOI: 10.18421/TRZ21.02-03
}

\begin{abstract}
In spite of the importance of tourists' risk perceptions for destinations in tourism literature, there is a limited research has been carried out in Turkey. The main purpose of this study is to examine foreign tourists' risk perceptions about Turkey. For this purpose, the study has been carried out by German tourists who visited to Antalya which is one of the important tourism destinations in Turkey in between March-December 2016. The results revealed the tourists' positive belief about safety of Turkey. The results also revealed that physical risk factor has a positive effect on the overall risk perception.
\end{abstract}

Keywords: Risk perception, perceived risk, Antalya, Turkey

\section{Introduction}

Tourism industry is one of the main components of the service industry. It has unique features of the service industry such as intangibility, inseparability, variability and degradability. But compared to other components of service industry, tourism industry is much more vulnerable. Events such as bad weather, hostile attitudes of local people, attentive behaviors of airport personnel, immunity of local food, terror, crime, political disorders, disease and natural disasters may negatively affect the industry (Fuchs, Reichel, 2011). The industry is particularly sensitive to safety and security issues (Seabra, et al., 2013).

In tourism literature, risk can be stated as a major source of concern for international travelers. The need for security is an innate feature of a person and safety concerns can prevent travel to certain destinations (Kozak, et al., 2007). Risk perception is defined as a cognitive assessment that affects tourist behavior. In other words, the risk perception of a tourist is significantly affected by events when buying or consuming tourism product, or perceptions about a destination. In this sense, it is assumed that tourits are rational, risk-averse consumers who prefer to safe destinations (Chahal, Devi, 2015). Tourists often prefer to destinations with low cost and low security risk. It is possible for tourists to take a negative attitude towards a destination when they think a destination unsafe or threatened. Therefore, they prefer destinations

\footnotetext{
Akdeniz University, Social Sciences Institute, Antalya, Turkey: yenalyagmur@hotmail.com

B Antalya Bilim University, College of Tourism, Antalya, Turkey; Corresponding author: oguz.dogan@antalya.edu.tr
} 
that are perceived as safer instead of the ones that are perceived as risky or insecure (Seabra, et al., 2013). Among the risks identified for tourism destinations are: health threats (e.g. food poisoning), terrorism, political instability (e.g. military coups), kidnapping, bombing and public demonstrations. Terrorism and political instability are often interpreted as potential risks due to uncontrollable, involuntary, and random nature of the potential damage that will occur in destinations where such events occur (Kapuściński, Richards, 2016).

Many destinations around the world are negatively affected by human-induced terrorism. For instance, in recent years, Turkey is one of the countries where terrorist incidents are frequent. In 2016, many terrorist incidents occured in Turkey. However, in 2016, about 25 million tourists visited to Turkey and this period Turkey generated about 22 billion dollars' income (Ministery of Culture and Tourism, 2017). When the number of tourists visiting the country is compared with the previous year, there is about 30\% decrease. It can be said that terrorist incidents that took place in the country affected the number of tourists visiting the country. From this point of view, it is aimed to determine general risk perceptions of tourists about Turkey in this study. For this purpose, a survey was conducted with 352 tourists who visited Antalya, one of Turkey's most important tourist destinations.

\section{Literature review}

The concept of risk concerns both the consequences of human activities and the undesirable consequences of a natural cause (Russell, Prideaux, 2014). According to Laws and Prideaux (2005) and Glaesser (2003), risk is likelihood of an unexpected event leading to possible negative consumer behavior (Reza, Samiei, 2012). Tulloch and Lupton (2003) suggested that the concept of risk generally refers to a pessimistic phenomenon. They also pointed out that the term is often paradoxically equivalent to words like bad or dangerous.

The concept of risk has a multi-dimensional structure (Yüksel, Yüksel, 2007). However, the literature identifies three type of risks; absolute, real and perceived risk (Reisinger, Mavondo, 2005). But Adam (2015) asserts that absolute risk and real risk are the same term. For this reson, he identifies two types of risk, absolute (real) and perceived risk. The absolute risk is an objective assessment of the potential of achieving an undesirable outcome. Perceived risk can be described as a subjectively determined expectation of a potential loss. Thus, perceived risk is seen as the individuals' perceptions of uncertain and negative consequences of buying a product/service or performing a certain activity (Adam, 2015).

The concept of perceived risk can be defined as a risk in terms of consumers' perceptions both of the uncertainty and the magnitude of the possible negative consequences (Yüksel, Yüksel, 2007). Keh and Sun (2008) define perceived risk as a subjective expectation of a loss. Moutinho (2000) suggests that perceived risk is a function of uncertainty and consequences. These functions are specific uncertainty of product, uncertainty of purchase types and place, level of financial and pyscho-social consequences and subjective uncertainty experienced by tourists (Jonas, et al., 2011).

Bauer (1960) claimed that the risk perception affects consumers' choises because of it plays major role in the pre-decision behavior of consumers (Reisinger, Mavondo, 2005). For instance; because of terrorist attack on September 11, the number of tourists visiting North America declined by $6.8 \%$ compared to previous year. The result of Tiananmen Square protests of 1989, about 11,500 tourists canceled visits to Beijing (Lepp, Gibson, 2003). SARS crisis in Hong Kong in 2003, Tsunami in 2005 in the Indian Ocean and suicede attacks to hotel enterpris- 
es in Middle East lead to a decrease in the number of tourists visiting countries (Kozak, et al., 2007). The elimination of risks is not possible. However, the risk perception can be reduced in tourism industry by early warning which can be obtained through risk assessments (Reisinger, Mavondo, 2005)

Risk perception may vary depending on destination or region. According to Sönmez and Graefe (1998) Canada, New Zealand, Switzerland, Sweden and Australia are perceived as the safest destinations in terms of risk perceptions; Iraq, Somalia, Libya, Lebanon and Syria are perceived as the most dangerous destinations. Schroeder et al., (2013) state that tourists tend to perceive Asia and North America as destinations with a high risk of natural disasters; Africa, South America, the Middle East and Asia are perceived by health-related risks. Therefore, risk perceptions are considered 'specific to the situation' or 'specific to the destination' (Schroeder, et al., 2013).

Early researches (see Roehl, Fesenmaier, 1992), examined the relationship between risk perceptions, travel pleasures of consumers and categorized tourism riks in seven dimensions including equipment or functional risk, financial risk, physical risk, psychological risk, satisfaction risk time risk and performance risk (George, 2010; Sharifpour, et al., 2014; Choo, et al., 2016). Recent researches (see Sönmez, Graefe, 1998; Seddighi, et al., 2001) also include political instability, health and terrorism risks as well as seven dimensions (Seabra, et al., 2013). Equipment or functional risk refers to possibility of mechanic, equipment or organizational problems occuring during the travel (Adam, 2015). Financial risk contains current expenditure related to initial purchase as well as subsequent costs related to initial purchase (Yüksel, Yüksel, 2007). In other words, financial risk refers to incurred financial loss that if the product needs to be repaired, changed or the price of the purchased product is refunded (Chahal, Devi, 2015). Because price is one of major demand factor in tourism industry, altough it isn't a decisive demand factor in many other service industries (Choo, et al., 2016). Pyhsical risk address to illness or injuries due to conditions such as air and hygiene problems or law and order (Tsaur, et al., 1997). Psychological risk can be defined as a risk that creates a negative effect on the consumers' quietude or personal perception based on product performance or selection. Psychological risk also states loss of ego or self-esteem due to the frustration that the inability to reach a purchasing intent. Another aspect of psychological risk is the possibility that the destination is not able to reflect the personality of the tourist and his/her own image (Choo, et al., 2016). Time risk focuses on the likelihood that a purchase can take a lot of time or cause a waste of time (Reza, Samiei, 2012). The satisfaction risk can be explained as the possibility that the travel experience can not provide personal satisfaction. Among other types of risk identified as being related to tourism, the performance risk is a potential loss due to corruption after the purchase of the product. The performance risk relates to consumer expectations of how well the product performs (Choo, et al., 2016).

Most researches focused on and have investigated perceived risk rather than the other types of risk (Reisenger, Mavondo, 2005; Seabra, et al., 2013). Because individuals are anxious about possible outcomes related to themselves (Seabra, et al., 2013). Kozak, et al. (2007) conducted a study on 1180 international travelers in Hong Kong in order to investigate the effects of percevied risk. As a result of the study, most of the travelers were determined that they have changed their travel plans to destinations with high risk. Result also shown that international travelers were sensitive to the occurrence of any kind of risk related to the destination, and that the perceived risk was different from one to another.

Fuchs and Reichel (2011), examined risk perception differences of first-time visitors and repeat visitors to highly unstable destinations. The study was conducted with 760 internation- 
al tourists who visited to Israel in between August-September 200o. The findings revealed that first-time visitors were associated with human-induced risk, socio-psychological risk, food safety and weather risk. On the contrary, repeat visitors were associated with service quality risk, natural disasters and financial risk.

The study conducted by Reza Jalilvand and Samiei (2012) carried out by 258 tourist visiting Isfahan-Iran. The results of the study revealed that there were concerns of visitors about pyshical, financial and psychological risks. Results also found out that personal characteristics of visitors such as gender, nationality, frequency of visits and purpose of visit affected the risk perceptions. However, age and duration of stay did not have a significant effect on risk perceptions.

Chahal and Devi (2015) examined the role of perceived risk in tourism destination qualities and destination image relationship and what type of risks are mostly related to domestic toursits visiting destinations. The study was conducted with domestic tourists who stayed at least 7 days in Keşmir. The findings found out that perceived risk affected significantly the relationship between destination qualities and destination image. Additionally, human-induced risk, financial risk and facility risk had negative effects on destination image.

Desivilya et al. (2015) compared the assessments of various risks by young Israeli students living in conflict zone and young Polish students who don't live in conflict zone and compared travel intentions to destinations with different risk types. The study was conducted with 713 Israeli and Polish students. The results showed that the risk assessments of Israeli students in terms of terror, health and natural disasters were higher than Polish' assessments. Also Israeli students were less likely to travel to destinations with different risk types than Polish students.

Yang et al. (2015) examined the risk perceptions of tourists visiting the eastern shores of the 'Sabah' which is considered high-risky place in Malaysia. According to the results of the study, tourists perceived the east coast of Sabah as high risky. But results revealed that although this negative perception on the east coast of Sabah, tourists continue to be optimistic about the other coastal regions of Malaysia.

\section{Methodology}

\section{Participants and Procedures}

The study conducted with tourists who visited Antalya, which is one of the most popular tourism destinations of Turkey. According to tourist numbers in Turkey, Antalya is the leader destination among the lead destinations worldwide. In 2013, Antalya is the fifth most visited destinations in the world and third in Europe (Çelik, 2014). Antalya is mostly preferred by German and Russian Tourists. In 2015, about three million German tourists visited to Antalya (AKTOB, 2015). For this reason, the study was conducted in Antalya and with German tourists.

It is not difficult to determine the size of the sample to be investigated by selecting from a certain class with a certain reliability interval. However, it is very difficult to reach a precise number of samples, since the variance of the population is generally unknown during the determination of the sample size. In such cases, the recommended method is to determine a preliminary sample within the study, to calculate the approximate value of the population variance from this preliminary sample, and to calculate a sufficient sample size for the study. Thus, more accurate and more reliable sample sizes can be determined (Delice, 2010). In this point of view, approximately three million German tourists who visited Antalya in 2015 were taken 
as the variance of the population in order to determine the sample. It was determined that with a sample error of $0.10,96$ tourists had the power to represent the population consisting of three million tourists. Accordingly, a survey was conducted with German tourists who visited Antalya between March 2016 and December 2016. Due to the recession in the country's tourism market during the period of the study, convenience sampling method was used. There are no criteria taken into consideration in convenience sampling. Everyone in a particular place is reached at a certain time (Kozak, 2014). The questionnaires were obtained by using face-toface survey technique from tourists participated in tours through professional tourist guides and 352 questionnaires were obtained.

\section{Measures}

The main purpose of this study is to examine the destination risk perceptions of tourists about Turkey. For this purpose, the study has been carried out by German tourists who visited to Antalya. There were numerous terrorist attacks in Turkey in 2016. The terrorist attacks are presented in Table 2. As can be seen in Table 1, terrorist attacks have occurred on all sides of Turkey. Despite these terrorist attacks, tourist arrivals continued. In this context, the destination risk perceptions scale (DRS), developed by Fuchs and Reichel (2006), was used. The scale includes 5 dimensions, namely, physical risk perception, financial risk perception, performance risk perception, socio-psychological perception and time risk perceptions. Respondents rated their destination risk perceptions by using 5-point Likert scale.

Table 1. List of Terrorist Attacks in 2016

\begin{tabular}{|c|c|c|c|c|}
\hline Date & Place & Killed & Injured & Explanation of Attacks \\
\hline 12 January 2016 & Istanbul & 11 & 15 & A suicide bomb attack in Sultanahmet in Istanbul. \\
\hline 17 February 2016 & Ankara & 29 & 61 & $\begin{array}{l}\text { A large bomb attack near a military barracks on } \\
\text { Eskisehir Road in Ankara. }\end{array}$ \\
\hline 13 March 2016 & Ankara & 38 & Over 120 & A bombing in Kizilay Square, central Ankara. \\
\hline 19 March 2016 & Istanbul & 5 & 36 & $\begin{array}{l}\text { A suicide bomb attack against tourists on Istiklal St in } \\
\text { Istanbul. }\end{array}$ \\
\hline 27 April 2016 & Bursa & 1 & 13 & A suspected suicide bomb attack at Bursa Ulu Mosque. \\
\hline 1 May 2016 & Gaziantep & 4 & 23 & A bomb attack at the Central Police Station \\
\hline 7 June 2016 & Istanbul & 13 & 36 & A bomb attack in the Vezneciler area of Istanbul \\
\hline 9 June 2006 & Diyarbakır & 2 & -- & An attack in Diyarbakır \\
\hline 28 June 2016 & Istanbul & 45 & 236 & Ataturk International Airport in Istanbul was attacked. \\
\hline 20 July 2015 & Sanlıurfa & 33 & Over 100 & $\begin{array}{l}\text { A suicide bomber, Sanlurfa province near the Syrian } \\
\text { border. }\end{array}$ \\
\hline 15 July 2016 & All around of Turkey & 246 & Over 3000 & $\begin{array}{l}\text { A coup d'état was attempted in Turkey against } \\
\text { state institutions, including, but not limited to the } \\
\text { government and President Recep Tayyip Erdoğan. The } \\
\text { attempt was carried out by a faction within the Turkish } \\
\text { Armed Forces that organized themselves as the Peace } \\
\text { at Home Council. }\end{array}$ \\
\hline 17 August 2016 & Van & 3 & 73 & An attack in central Van against a police station \\
\hline 18 August 2016 & Elazıg & 6 & Over 210 & Bombed vehicle attack to Elazıg police headquarters \\
\hline 20 August 2016 & Gaziantep & 57 & Over 90 & An attack on a wedding party in Gaziantep \\
\hline
\end{tabular}




\begin{tabular}{|c|c|c|c|c|}
\hline Date & Place & Killed & Injured & Explanation of Attacks \\
\hline 24 August 2016 & Antalya & -- & 2 & $\begin{array}{l}\text { A roadside bomb injured } 2 \text { Gendarmerie officers on the } \\
\text { Antalya - Kemer road near Topcam. }\end{array}$ \\
\hline 26 August 2016 & Sirnak & 13 & 78 & $\begin{array}{l}\text { An attack at a police checkpoint with bomb-laden } \\
\text { truck and }\end{array}$ \\
\hline 12 September 2016 & Van & -- & Over 50 & An attack at a police checkpoint. \\
\hline 16 September 2016 & Gaziantep & 5 & 13 & $\begin{array}{l}\text { During the raid on the home of a district police units in } \\
\text { Sahinbey, the explosive on the attacker at home were } \\
\text { exploded. }\end{array}$ \\
\hline 4 October 2016 & Diyarbakır & 12 & Over 100 & $\begin{array}{l}\text { A Bombed vehicle attack to Diyarbakir police } \\
\text { headquarters }\end{array}$ \\
\hline 6 October 2016 & Istanbul & -- & -- & $\begin{array}{l}\text { An explosion occurred near a police headquarters in } \\
\text { the Yenibosna area on the European side of Istanbul }\end{array}$ \\
\hline 10 October 2015 & Ankara & 100 & Over 180 & $\begin{array}{l}\text { There were } 2 \text { explosions near the main train station in } \\
\text { the Ulus area of Ankara. }\end{array}$ \\
\hline 14 October 2016 & $\begin{array}{l}\text { Hakkari, Van, } \\
\text { Adiyaman, Diyarbakir }\end{array}$ & -- & 13 & Attacks took place against the Turkish military \\
\hline 24 November 2016 & Adana & 2 & 21 & A bomb exploded near the Governor's Office \\
\hline 10 December 2016 & Istanbul & 48 & Over 150 & $\begin{array}{l}\text { A car bomb exploded near the Besiktas football } \\
\text { stadium in the Macka/Dolmabahce area of Istanbul. }\end{array}$ \\
\hline 17 December 2016 & Kayseri & 15 & Over 50 & $\begin{array}{l}\text { A suspected car bombing in Kayseri, Turkey. The soldiers } \\
\text { - all low-ranking privates and non-commissioned } \\
\text { officers - had been given permission for leave from the } \\
\text { commando headquarters in the city. }\end{array}$ \\
\hline 19 December & Ankara & 1 & -- & $\begin{array}{l}\text { Russia's ambassador to Turkey was assassinated at an } \\
\text { Ankara art exhibit. }\end{array}$ \\
\hline 01 January 2017 & İstanbul & 39 & 69 & An attack on the Reina nightclub in Ortakoy \\
\hline
\end{tabular}

Sources:https://www.gov.uk/foreign-travel-advice/turkey/safety-and-security; https://www.nytimes.com/interactive/2016/12/31/world/ europe/turkey-recent-attacks.html?_r=0; https://storymaps.esri.com/stories/terrorist-attacks/?year=2016; https://en.wikipedia.org/wiki/ Category:Terrorist_incidents_in_Turkey_in_2016.

Reliability of the scale was obtained by calculating Cronbach's Alpha coefficient. The general Cronbach's Alpha coefficient of the scale is $\alpha=0.851$. This value shows that the scale is reliable (Hair, et al., 1998).

\section{Results}

The demografic profile of respondents are presented in Table 2. As shown in Table 2, of the 352 respondets, $58,2 \%$ were female, $52 \%$ were married, $38,4 \%$ were $25-34$ age category and $83,2 \%$ visited to Turkey for the first time.

Table 3 provides the means and standart deviations of overall risk perceptions. As seen in table, the statements, "Turkey is a safe country for tourists" and "My friends or relatives see Turkey as a risky place to visit", are higher means (3.84 and 3.06) than other statements. The statement that the overall risk perception during the visit in Turkey, "Considering your experience in Turkey so far, in terms of risk, I would evaluate as the most dangereous country", is the lowest mean (1.85). 
Table 2. Demographics of the Respondents

\begin{tabular}{|c|c|c|c|}
\hline \multirow{4}{*}{ Gender } & Male & Frequency & Percentage (\%) \\
\cline { 2 - 4 } & Female & 147 & 41.8 \\
\hline \multirow{4}{*}{ Age Group } & $18-24$ & 205 & 58.2 \\
\cline { 2 - 4 } & $25-34$ & 54 & 15.3 \\
\cline { 2 - 4 } & $35-44$ & 135 & 38.4 \\
\cline { 2 - 4 } & $45-54$ & 55 & 15.6 \\
\cline { 2 - 4 } & $55-64$ & 44 & 12.5 \\
\hline \multirow{4}{*}{ Number of Visits } & 65 or above & 45 & 12.8 \\
\cline { 2 - 4 } & First time & 19 & 5.4 \\
\cline { 2 - 4 } & Second times & 293 & 83.2 \\
\cline { 2 - 4 } & Third times & 44 & 12.5 \\
\cline { 2 - 4 } & Fourth times & 5 & 1.4 \\
\hline
\end{tabular}

Table 3. Means and Standard Deviations of Overall Risk Perceptions

\begin{tabular}{|l|c|c|}
\hline Statements & Mean & Std. Deviation \\
\hline Turkey is a safe country for tourists. & 3.84 & .79 \\
\hline $\begin{array}{l}\text { I thought that my friends would worry about my safety while I was in } \\
\text { Turkey. }\end{array}$ & 3.08 & 1.15 \\
\hline $\begin{array}{l}\text { Prior to my trip, I was viewing Turkey as more dangerous than other } \\
\text { places around the world. }\end{array}$ & 2.44 & 1.12 \\
\hline $\begin{array}{l}\text { Considering your experience in Turkey so far, in terms of risk, I would } \\
\text { evaluate as the most dangerous country. }\end{array}$ & 1.85 & 1.00 \\
\hline \begin{tabular}{l} 
My friends or relatives see Turkey as a risky place to visit. \\
\hline
\end{tabular} & 3.06 & 1.17 \\
\hline
\end{tabular}

Factor analysis was using in order to determine the factor structure of destinastion risk perceptions questionnaire. Varimax rotation was used. 29 items of destinastion risk perceptions questionnaire inclueded in factor analysis. 3 items that factor loadings less than 0.50 were exclueded from analysis. Kaiser-Meyer-Olkin value was .900 and Barttlett test (o.00o, Chi-Square: 7799,195 , df: 0.325$)$. This results indicated that the sample suitable for factor analysis. In this context, 5 factors were obtained and this factors are explaining $71.336 \%$ of the total variance which is above the acceptable value (Nakip, 2003). The Cronbach's Alpha values of the factors ranged from 0.85 to 0.92 which indicated that the scale is reliable (Hair, et al., 1998).

Table 4. Results of Factor Analysis

\begin{tabular}{|l|c|c|c|}
\hline Factors & Factor loadings & \% variance & Cronbach Alpha \\
\hline Factor 1: Physical Risk & & 20.679 & 0.85 \\
\hline Prior to my trip, I worried about food safety problems in Turkey & .535 & & \\
\hline $\begin{array}{l}\text { Prior to my trip, I worried about that there might be epidemic } \\
\text { diseases in Turkey }\end{array}$ & .785 & & \\
\hline $\begin{array}{l}\text { Prior to my trip, I worried about natural disasters in Turkey } \\
\text { such as earthquakes, floods and storms }\end{array}$ & .763 & & \\
\hline
\end{tabular}




\begin{tabular}{|c|c|c|c|}
\hline Factors & Factor loadings & $\%$ variance & Cronbach Alpha \\
\hline I worried about getting injured in an car accident in Turkey & .610 & & \\
\hline $\begin{array}{l}\text { I worried before my trip about crime (theft, robbery, } \\
\text { pickpockets) in Turkey }\end{array}$ & .607 & & \\
\hline I worried about terrorism in Turkey & .864 & & \\
\hline $\begin{array}{l}\text { I worried about being exposed to danger due to political unrest } \\
\text { in Turkey }\end{array}$ & .812 & & \\
\hline $\begin{array}{l}\text { Prior to my visit, I worried that my behavior would not be well } \\
\text { received by some Turks (including the way I customarily dress) }\end{array}$ & .616 & & \\
\hline Factor 2: Financial Risk & & 18.225 & 0.88 \\
\hline $\begin{array}{l}\text { Prior to my trip, I worried that I would not receive good value } \\
\text { for my money }\end{array}$ & .645 & & \\
\hline $\begin{array}{l}\text { I worried that the trip to Turkey would involve unexpected } \\
\text { extra expenses (such as changes in exchange rates, extra costs } \\
\text { in hotels) }\end{array}$ & .708 & & \\
\hline $\begin{array}{l}\text { I worried that the trip to Turkey would be more expensive than } \\
\text { other international trips }\end{array}$ & .599 & & \\
\hline $\begin{array}{l}\text { I worried that the trip to Turkey would involve more incidental } \\
\text { expenses than I had anticipated, such as clothing, maps, sports } \\
\text { equipment, babysitters }\end{array}$ & .693 & & \\
\hline $\begin{array}{l}\text { I worried that the trip to Turkey would have an impact on my } \\
\text { financial situation }\end{array}$ & .692 & & \\
\hline Factor 3: Performance Risk & & 15.318 & 0.87 \\
\hline I worried that the hotels in Turkey would be unsatisfactory & .707 & & \\
\hline I worried that sites would be too crowded & .540 & & \\
\hline I worried that the food in turkey would not be good & .618 & & \\
\hline I worried that the Turks would not be friendly & .761 & & \\
\hline $\begin{array}{l}\text { I worried that Turkish hospitality employees would not be } \\
\text { courteous to international tourists }\end{array}$ & .651 & & \\
\hline Factor 4:Socio-Psychological Risk & & 9.470 & 0.92 \\
\hline $\begin{array}{l}\text { I worried that a trip to Turkey would not be compatible with } \\
\text { my self-image }\end{array}$ & .724 & & \\
\hline $\begin{array}{l}\text { I worried that my trip to Turkey would change the way my } \\
\text { friends think of me }\end{array}$ & .867 & & \\
\hline $\begin{array}{l}\text { I worried before my trip that I would not receive personal } \\
\text { satisfaction from the trip to Turkey }\end{array}$ & .684 & & \\
\hline $\begin{array}{l}\text { I worried that my trip to Turkey would change the way my } \\
\text { family thinks of me }\end{array}$ & .832 & & \\
\hline $\begin{array}{l}\text { I worried that my trip to Turkey would change the way my } \\
\text { status in life (social class) }\end{array}$ & .757 & & \\
\hline Factor 5: Time Risk & & 7.645 & 0.92 \\
\hline $\begin{array}{l}\text { Prior to my trip, I worried that the trip to Turkey would be a } \\
\text { waste of time }\end{array}$ & .580 & & \\
\hline I worried that my trip would waste my valuable vacation time & .762 & & \\
\hline $\begin{array}{l}\text { I worried that planning and preparing for the trip would take } \\
\text { to much time }\end{array}$ & .611 & & \\
\hline
\end{tabular}

Total variance (\%): 71.336 Kaiser-Meyer-Olkin: .900 df: .325

Bartlett significance value: .000 Chi-Square: 7799, 195 
Pearson correlation analysis was used to examine the relationship between the factors determined by factor analysis. The results of correlation analysis are shown in Table 5 . If correlation coefficients are between 0.70-1.00, there is high relation; if it's between 0.70-0.30, there is moderate relation; if it's between 0.30-0.oo, there is a low relation (Büyüköztürk, 2012). As shown in Table 5, there are high and positive correlations between financial risk and physical risk, between performance risk and financial risk, between socio-psychological risk and time risk.

Table 5. Correlations Between Risk Factors And Overall Risk

\begin{tabular}{|c|c|c|c|c|c|c|c|}
\hline & & Overall Risk & Physical Risk & $\begin{array}{c}\text { Financial } \\
\text { Risk }\end{array}$ & $\begin{array}{c}\text { Performance } \\
\text { Risk }\end{array}$ & $\begin{array}{c}\text { Socio- } \\
\text { Psychological Risk }\end{array}$ & Time Risk \\
\hline Overall Risk & $r$ & 1 & & & & & \\
\hline Physical Risk & $r$ & $0.542 * *$ & 1 & & & & \\
\hline Financial Risk & $\mathrm{r}$ & $0.338 * *$ & $0.715^{* *}$ & 1 & & & \\
\hline Performance Risk & $\mathrm{r}$ & $0.284^{* *}$ & $0.600 * *$ & $0.701^{* *}$ & 1 & & \\
\hline $\begin{array}{l}\text { Socio- } \\
\text { Psychological Risk }\end{array}$ & $r$ & $0.262 * *$ & $0.589 * *$ & $0.633^{* *}$ & $0.620 * *$ & 1 & \\
\hline Time Risk & $r$ & $0.209 * *$ & $0.468 * *$ & $0.568 * *$ & $0.659 * *$ & $0.775^{* *}$ & 1 \\
\hline
\end{tabular}

${ }^{*} p<0.05,{ }^{* *} p<0.01$

Multiple regression analysis was carried out by using overall risk perceptions as a dependent variable and risk factors as independent. It can be stated that there is no multiple correlation problem since the tolerance values are higher than o.1. The Durbin-Watson coefficient, which indicates whether autocorrelation problem among the variables in the model, should be less than two. In our model, the Durbin-Watson coefficient is 1.741. Within this context, there is no autocorrelation problem among the variables (Deniz, 2016). The regression model is significant ( $\mathrm{R} 2$ : 0.301; F: 29.834; $\mathrm{p}<0.05)$. The model explains $68 \%$ of the dependent variable. According to the results, physical risk perception has a positive and significant effect on the overall risk perception ( $\beta$ :0.599; $\mathrm{p}<0.05)$.

Table 6. Multiple Linear Regression Analysis

\begin{tabular}{|l|c|c|c|c|c|}
\hline & $\beta$ & $\mathrm{t}$ & $\mathrm{P}$ & Tolerance & VIF \\
\hline Constant & 1.762 & 19.899 & 0.000 & &. \\
\hline Physical Risk & .599 & 9.403 & 0.000 & .443 & 2.259 \\
\hline Financial Risk & -.056 & -.927 & 0.355 & .355 & 2.818 \\
\hline Performance Risk & -.012 & -.205 & 0.838 & .396 & 2.524 \\
\hline Socio-Psychological Risk & -.061 & -.896 & 0.371 & .324 & 3.085 \\
\hline Time Risk & .013 & .205 & 0.838 & .341 & 2.934 \\
\hline
\end{tabular}

$R^{2}$ : 0.301; F: 29.834; p: 0.000; Adj R2:0.291

Durbin-Watson: 1.741 


\section{Conclusions}

Tourism industry has become one of the most important industries. The economic well-being of developing countries or underdeveloped zones of developed countries depend on tourism industry (Desivilya, et al., 2015). Various strategic plans time to time are made by destination marketers and government authorities to enhance the flow of tourists (Chahal, Devi, 2015). But the industry is very vulnerable to the effects of various tragic events such as natural disasters and terrorist attacks (Desivilya, et al., 2015). Especially, terrorist attacks affect unfavorably the industry. Nowadays, many destinations around the world are negatively affected by human-induced terrorism. It can be stated that the number of tourists who visited the destinations decreased, because of the human-induced terrorism. The safety concerns can prevent travel to certain destinations.

It is aimed to examine general risk perceptions of tourists about Turkey in this study. Accordingly, a survey was conducted with German tourists who visited Antalya between March 2016 and December 2016. Antalya is very important for Turkish tourism industry. In 2015, about 11 million tourists and in 2016, about 6 million tourists visited the destination (TÜRSAB, 2017). This study may provide a perspective on foreign tourists' risk perceptions about Turkey. The results of the study revealed that the tourists believe that Turkey is a safe country. Although $83.2 \%$ of the participants were first-time visitors, they think that the Turkey is safe. Terrorist attacks in Antalya are rare, compares with other provinces in Turkey. Therefore, the participants were optimistic about the country. It can be stated that tourists who are far from places where terrorist attacks are happened, have positive thoughts about the country.

There is a strong relationship between the overall risk perceptions of tourists and "physical risk". Also, according to the results of multiple regression analysis, physical risk factor has a positive effect the overall risk perception. In other words, If the physical risk perception increases, the overall risk perception will also increase. This result migt be because of terrorist attacks in the country. Safety has become most important issue for tourism industry due to the large number of terrorist attacks occured all around the world. So, it can be stated that the tourists perceive the countries where physical attacks are happened as a dangerous destination. There is no relationship between other risk factors (financial risk, performance risk, socio-psyhological risk and time risk) and overall risk perceptions in this study. This can be explained by cultural differences of participants.

In this study, it was examined the foreign tourists' general risk perceptions about Turkey who visited Antalya. The results of this study may provide a basis of comparison for further research on destination risk perception and repeat visitors. Furthermore, destination risk perceptions of the tourists who plan to visit Antalya before and after arriving at the destination can be compared. Also this study can be conducted to other destinations in Turkey to verify the findings.

The main limitation of the study is that carried out in a single destination and with a specific tourist group. Thus, transferability of the findings is limited. Other tourist groups may represent different forms of risk perceptions. Another limitation is the small number of samples in which the study was conducted in 2016, which is a tragic period for the Turkish tourism sector. 


\section{References}

Adam, I. 2015. Backpackers' Risk Perceptions and Risk Reduction Strategies in Ghana. Tourism Management 49, 99-108.

Akdeniz Turistik Otelciler ve İşletmeciler Birliği (AKTOB) (2015). AKTOB Newsletter. Retrieved from http://www.aktob.org.tr/pdf/AKTOB.BULTEN.KASIM.2015.pdf, downloaded March 10, 2017. (In Turkish)

Chahal, H., Devi, A. 2015. Destination Attributes and Destination Image Relationship in Volatile Tourist Destination: Role of Perceived Risk. Metamorphosis: A Journal of Management Research 14, 2, 1-19.

Chew, E. Y. T., Jahari, S. A. 2014. Destination Image as a Mediator Between Perceived Risks and Revisit Intention: A Case of Post-Disaster Japan. Tourism Management 40, 382-393.

Choo, H.K., Choo, Y., Kang, H.M. 2016. Do Sport Tourists' Perceived Risks Affect Their Involvement and Intention to (Re)Visit? An Empirical Study for Risk-Reduction Strategies. International Journal of Sports Marketing and Sponsorship 17, 1, 19-36.

Çelik, P. 2014. A Sustainable Destination Model Proposal and Competition Analysis of Antalya in Terms of Destination Competitiveness. Unpublished PhD Thesis, Akdeniz University, Social Sciences Institute, Antalya. (In Turkish)

Delice, A. 2010. Problem of Sampling in Quantitative Researches. Cal 13/2, 151-170. (In Turkish)

Deniz, G. 2016. The Effect of Personality and Socialization on Emotional Labor: Case of Boutique Hotel. Anatolia: Turizm Araştırmaları Dergisi 27/2, 273-289. (In Turkish)

Desivilya, H., Teitler-Regev, S., Shahrabani, S. 2015. The Effects of Conflict on Risk Perception and Travelling Intention of Young Tourists. EuroMed Journal of Business 10/1, 118-130.

Eitzinger, C., Wiedemann, P. 2007. Risk Perceptions in the Alpine Tourist Destination TyrolAn Exploratory Analysis of Residents' Views. Tourism Management 28/3, 911-916.

Fuchs, G., Reichel, A. 2006. Tourist Destination Risk Perception: The Case of Israel. Journal of Hospitality \& Leisure Marketing 14/2, 83-108.

Fuchs, G., Reichel, A. 2011. An Exploratory Inquiry into Destination Risk Perceptions and Risk Reduction Strategies of First Time vs. Repeat Visitors to A Highly Volatile Destination. Tourism Management 32/2, 266-276.

George, R. 2010. Visitor Perceptions of Crime-Safety and Attitudes Towards Risk: The Case of Table Mountain National Park, Cape Town. Tourism Management 31/6, 806-815.

Hair, J. F., Black, W. C., Babin, B. J., Anderson, R. E., Tatham, R. L. 1998. Multivariate Data Analysis, Upper Saddle River.

Jonas, A., Mansfeld, Y., Paz, S., Potasman, I. 2011. Determinants of Health Risk Perception Among Low-Risk-Taking Tourists Traveling to Developing Countries. Journal of Travel Research 50/1, 87-99.

Kapuściński, G., Richards, B. 2016. News Framing Effects on Destination Risk Perception. Tourism Management 57, 234-244.

Keh, H. T., Sun, J. 2008. The Complexities of Perceived Risk in Cross-Cultural Services Marketing. Journal of International Marketing 16/1, 120-146.

Kozak, M., Crotts, J. C., Law, R. 2007. The Impact of the Perception of Risk on International Travellers. International Journal of Tourism Research, 9/4, 233-242.

Lepp, A., Gibson, H. 2003. Tourist Roles, Perceived Risk and International Tourism. Annals of Tourism Research 30/3, 606-624.

Ministery of Culture and Tourism (2017). http://yigm.kulturturizm.gov.tr/TR,72942/turizm-gelir-gider-ve-ortalama-harcama.html, March 18, 2017. 
Moreira, P. 2007. Stealth Risks and Catastrophic Risks: On Risk Perception and Crisis Recovery Strategies. Journal of Travel and Tourism Marketing 23/2, 15-28.

Nakip, M. 2003. Marketing Researches: Techniques and Applications. Seçkin Kitabevi, Ankara. (In Turkish)

Reisinger, Y., Mavondo, F. 2005. Travel Anxiety and Intentions to Travel Internationally: Implications of Travel Risk Perception. Journal of Travel Research 43/2, 212-225.

Reza Jalilvand, M., Samiei, N. 2012. Perceived Risks in Travelling to the Islamic Republic of Iran. Journal of Islamic Marketing 3/2, 175-189.

Russell, C., Prideaux, B. 2014. An Analysis of Risk Perceptions in A Tropical Destination and a Suggested Risk Destination Risk Model. Advances in Hospitality and Leisure 10, 91-109.

Schroeder, A., Pennington-Gray, L., Kaplanidou, K., Zhan, F. 2013. Destination Risk Perceptions Among US Residents for London as the Host City of the 2012 Summer Olympic Games. Tourism Management 38, 107-119.

Seabra, C., Dolnicar, S., Abrantes, J. L., Kastenholz, E. 2013. Heterogeneity in Risk and Safety Perceptions of International Tourists. Tourism Management 36, 502-510.

Sharifpour, M., Walters, G., Ritchie, B. W. 2014. Risk Perception, Prior Knowledge and Willingness to Travel: Investigating the Australian Tourist Market's Risk Perceptions Towards the Middle East. Journal of Vacation Marketing, 20/2, 111-123.

Sönmez, S. F., Graefe, A. R. 1998. Influence of Terrorism Risk on Foreign Tourism Decisions. Annals of Tourism Research 25/1, 112-144.

Tezbaşaran, A. (1997). A Guide for Developing Likert Type Scale, Türk Psikologları Derneği, Ankara. (In Turkish)

Türkiye Seyahat Acentaları Birliği (TÜRSAB) (2017). http://www.tursab.org.tr/tr/turizm-verileri, April 12, 2017.

Yang, E. C. L., Sharif, S. P., Khoo-Lattimore, C. 2015. Tourists' Risk Perception of Risky Destinations: The Case of Sabah's Eastern Coast. Tourism and Hospitality Research 15/3, 206221.

Yeung, R. M., Yee, W. M. 2013. Risk Measurement Framework: An Extension and Validation of Food Safety Risk in International Travel Destinations. British Food Journal 115/8, 1073-1089.

Yüksel, A., Yüksel, F. 2007. Shopping Risk Perceptions: Effects On Tourists' Emotions, Satisfaction and Expressed Loyalty Intentions. Tourism Management 28/3, 703-713.

Internet 1: https://www.gov.uk/foreign-travel-advice/turkey/safety-and-security (18.03.2017.)

Internet 2: https://www.nytimes.com/interactive/2016/12/31/world/europe/turkey-recent-attacks.html?_r=o (18.03.2017.)

Internet 3: https://storymaps.esri.com/stories/terrorist-attacks/?year=2016 (18.03.2017.) 